\title{
LAS PELÍCULAS DE VARGAS LLOSA
}

\author{
Carlos Ossa \\ Universidad de Chile \\ anis626@yahoo.es
}

\section{RESUMEN / ABSTRACT}

El artículo revisa las vinculaciones estético-políticas que la obra de Mario Vargas Llosa mantiene con el cine y enfatiza la permanente conexión entre palabra e imagen que hay en sus novelas más conocidas. Una correspondencia entre cine y literatura, pues son el modo que tiene el autor peruano de imaginar la identidad y sus figuras.

Palabras Clave: visualidad, representación, traducción, comunidad, Perú.

The article points out the relation between film and literature in the work of Mario Vargas Llosa, especially between word and image in some of his most well-known novels. This relation suggests that to configure his characters and their identity, Vargas Llosa requires both: text and images, literature and film.

KEY WORDS: image, representation, translation, community, Peru.

En 1927 se estrenó Luis Pardo, un film social de Enrique Cornejo Villanueva que reivindicaba el heroísmo agrario de un joven que se había rebelado contra la ley de castas dominante en el Perú rural. Era uno de los primeros intentos de dar visibilidad a la población mestiza usando las metáforas de la ingenuidad étnica y la naturaleza justa. El cuerpo -hasta ese momento escondido-de los campesinos servía de motivo auxiliar a la lucha del bandolero mitificado en héroe.

Una paradoja define a este film: el montonero blanco enseña a los indios como ser modernos bajo las normas de la costumbre, la pedagogía y la 
justicia social. La puesta en escena sugiere una mirada paternalista que sumerge al colectivo en un rol secundario e ilustrativo de las hazañas del bandido. Estas condiciones subordinan el protagonismo de la comunidad al imaginario cinematográfico ${ }^{1}$. Entran a la imagen a mostrar un cuerpo físico y sirven de mímesis racial a una cultura que los observa con el tiempo de las máquinas: indigenismo y tecnicidad producen una corporeidad extraña y única, la identidad se relata con las reglas del montaje. Un problema que se hace evidente es el encuadre de los sujetos al formato y la esquematización de los mismos en el instante de su exhibición. Reconocer la existencia étnica y castigarla en el anuncio de su impropiedad.

¿Quién decide lo visible? ¿Qué escrituras devuelven al cuerpo la materialidad mutilada por los símbolos estereotipados? El cine peruano se enfrenta a estas preguntas y otras relacionadas con el dar a ver, permitir ver y hacer ver. Existe un "otro" imposible de dejar fuera del relato, ¿cómo incluirlo? Una posibilidad es bajo la forma clasista, didáctica o xenofóbica de mostrar a la etnia unida a la infancia de la nación: Manuel Trullen o Amauta Films, la Escuela de Cusco. La otra opción es recuperar la historia cultural y fundar una antropología de la imagen llenándose con la multitud que viene: el grupo $\mathrm{Chaski}^{2}$. De esta manera domina en la filmografía peruana una tensión entre reconocer y negar la multiplicidad de signos, discursos e imágenes existentes en la nación. Sin embargo, la relación entre cine y literatura también sufre este conflicto que obliga a disciplinar o poetizar los rostros y cuerpos de quienes se introducen en el canon letrado desde la visualidad y provocan la pugna del trazo y la marca cuyas tareas de escribir y significar nunca concluyen.

${ }^{1}$ En Cultura e Imperialismo (1993) Edward Said confirma la importancia de las narraciones y los relatos en la construcción de la historia y las identidades. Ella Shoat y Robert Stam (2002) describen como el cine establece ideas sobre el tiempo y el espacio de las culturas marginadas. Charles Silet (1980) muestra la tendencia de la cinematografía dominante a aplanar, suspender o mezclar las diferencias culturales, geográficas y simbólicas con el modelo del indio instantáneo. Juan Arellano (2008) ilustra lo anterior con su análisis de la cuarta entrega de la saga de Indiana Jones y el Reino de la Calavera de Cristal en el Perú.

2 A principios de los años 80 se formó el colectivo con Fernando Espinoza, Alejandro Legaspi, Stefan Kaspar, René Weber, Oswaldo Carpio, María Barea y Susana Pastor. Su proyecto era documentar la realidad urbana-indígena ambientando las películas en los barrios pobres y marginales de Lima. El grupo produjo Gregorio (1984) y Juliana (1986), dos significativas lecturas sobre de la problemática de los niños de la calle. 
La distancia aberrante y banal entre indígenas y criollos, el abismo ontológico que los ata a vivir en el mismo territorio, pero en diferente lugar, es un tema inevitable del amargo relato nacionalista. Los pánicos institucionales, las soberbias urbanas, los resentimientos plebeyos, los modales cínicos y las muertes mudas son el archivo común de la palabra ilustrada y la imagen cinematográfica. Los escritores peruanos que asumen este archivo y se entregan a su análisis y crítica han reconocido el dilema de la modernización: la identidad es convertida en la expresión estructural de la desigualdad. Entre ellos, Mario Vargas Llosa, polémico y prolífico, construye una galería de individuos castigados y arrastrados por esta lógica al interior de la prosa del mundo burgués, a contrapelo convierte su obra en un imaginario donde lo popular y lo castizo no pueden dejar de luchar por la tradición y la modernidad. Su trabajo que pasa del romanticismo criollo al individualismo nihilista tiene la compleja virtud de hacer del lenguaje el protagonista de la escritura y ocultarse en ella. Los Jefes (1959) y La Ciudad y los Perros (1963) apelan a un realismo ético basado en la denuncia y la redención. El hilo de ambos relatos se refiere a la obligación de vivir, de diverso modo, el castrense engaño de la disciplina, la derogación del deseo o las naturalizadas relaciones de clase. Son materiales de lucha convencidos de herir la espiritualidad conservadora de la ortodoxia cristiana limeña. Pero su capacidad de ruptura no se valida por el contenido de querella y sarcasmo, sino por la presencia de un código de época que celebra el momento donde la literatura no teme a la militancia, al contrario, imagina encontrar con ella un después. Ese después es el cine, campo que Mario Vargas Llosa incorpora permanentemente y que en los años setenta lo ayudó a pensar en la realidad latinoamericana como una masa de silencios y subterfugios "cómplices" de un poder esquivo y punitivo que gustaba maltratar el cuerpo y lastimar los mitos.

Es un periodo que convoca a los escritores a fundar una literatura experimental y objetiva; vanguardista y comprometida; nacional y revolucionaria para producir un fenómeno nuevo: la sociedad en texto. Incorporar la heteronomía estética y comunicacional del Perú es un modo de cancelar el encierro identitario de los otros. Es dable reconocer una estética política en Mario Vargas Llosa cuyo modelo se basa en la idea de una representación emancipada ocurriendo en el acto de narrar. Al menos en los años setenta y ochenta se podría reconocer que sus escritos se vuelcan a un ejercicio dialéctico que acepta la visualidad como un tropo y un límite narrativo. Describe lo anterior el conjunto de siete películas que han sido presentadas teniendo como base la narrativa 
del escritor. Cachorros (1972), dirección y guión de Jorge Fons y apoyo de Eduardo Luján; Pantaleón y las Visitadoras (1975), codirigida por Mario Vargas Llosa y José María Gutiérrez Santos; en este film el escritor además actúa como soldado; La Ciudad y los Perros (1985), exitosa propuesta de Francisco Lombardi y adaptada por José Watanabé; Yaguar (1986), versión rusa de la misma película dirigida por el director chileno Sebastián Alarcón; Tune in Tomorrow (1990), versión norteamericana de La Tía Julia y el Escribidor, dirigida por Jon Amiel; Pantaleón y las Visitadoras (1999), de Francisco Lombardi; La fiesta del Chivo (2005), dirigida por Luis Llosa y guión de Augusto Cavada.

La versión fílmica de Los Cachorros (1972), hecha por Jorge Fons, no pretende una copia perfecta, tampoco un original sin errores, es una obra ambigua, una traducción pendiente. En 1975, Mario Vargas Llosa dirige Pantaleón y las Visitadoras, en un ejercicio muy propio del periodo con sus ideas de experimentar con nuevos registros; a su vez, se vive la discusión sobre la incapacidad de la literatura de instalarse en su evidencia. Dos cosas se hacen notorias con este film, en una, se realiza la operación modernista de arruinar la autenticidad del autor y, en la otra, sospechar de las competencias del traductor: aunque están unidos por un tejido histórico-Perú militarizado, frontera voluptuosa, eficiencia burocrática y sexualidad controlada-, no pueden discutir la misma experiencia. Cambios y movimientos, traspasos y suposiciones arman las estrategias de unos textos (novela y film) que son discursos distintos, a pesar de la falsa mimesis que dicen respetar. Separados por dificultades prácticas, contextuales y artísticas, los materiales no saben de antemano que son intraducibles, pero albergan la esperanza de una adivinación, esperan un descubrimiento teñido de convicción estética capaz de arrancar de la mudez histórica aquello que no se leyó, en su minuto, y no se leerá después.

No existe una comunidad de sujetos preexistentes al lenguaje que se trasmitan algo a través de él, sino solo una lengua que comunica la esencia espiritual que le corresponde. De tal principio se extrae una doble consecuencia: primero, que la estructura de la comunicación no es horizontal -o simétrica: llegará a serlo solo en el tiempo de la propia decadencia jurídica-sino vertical (...) Y, segundo que la lengua humana es definida por una falta, por una ausencia, que determina una red insuperable de expresado e inexpresado, de comunicable e 
incomunicable, de voz y silencio desde dentro de la propia palabra" (Expósito 138).

Por lo mismo, Pantaleón y las Visitadoras instala un problema político-formal lentamente verificado por las hermenéuticas contemporáneas: la realidad no tiene un espejo en la literatura, una superficie de signos se acomoda -ahídonde antes se imaginó una historia. Las tretas visuales convocadas a dar forma a los personajes no son adaptaciones del lenguaje, sino quiebres de escritura. Lo representado no imita lo real, más bien, le da la ocasión de vivir un escenario de sentido. En general podríamos indicar que los escritores latinoamericanos que tienen versiones fílmicas de sus obras enfrentan una "experiencia medial" que no siempre reflexionan. Una temporalidad y un montaje que deshace la arquitectura literaria al introducir un régimen de verosimilitud donde las cosas resplandecen al ritmo de la secuencia y el plano. A su vez, la fuerza que tiene como matriz cultural el realismo, sea social, poético, mágico o sucio, en América Latina muestra el desplazamiento de los contenidos y las formas literarias desde las estrategias autonómicas del modernismo a las marginalidades narrativas de la poscolonialidad. Bajo este contexto la literatura que primero imaginó un pacto entre intelectual y nación, ahora acepta un convenio entre productor y mercado. Los límites se pierden en el proceso de construcción textual, pues no hay forma pura y la cultura impone sus objetos a las palabras. Un mérito de la narrativa de Mario Vargas Llosa es la capacidad de aplacar la dispersión epocal en la coherencia imaginaria del lenguaje, usando para ello imágenes que están fuera del régimen convencional de la novela y la polis.

La versión de Francisco Lombardi de 1985 justifica lo dicho hasta ahora, pues el realizador inventa una selva donde soldados y mujeres sirven a un principio taylorista del sexo; organizan una economía militar de alcances civiles; retratan la subordinación del cuerpo a los imperativos del "jefe"; idealizan a la amante-naturaleza contra la esposa-ciudad; confrontan la moral de las instituciones con las imágenes de un deseo soberano; contrastan la dimensión oblicua del poder con la certeza normativa del mando; yuxtaponen la visualidad explosiva de la frontera geográfica con la abstracta devoción nacionalista a la bandera; defienden una etnicidad trágico-cómica frente a la violencia normalizadora de la cultura blanca. El desplazamiento es tal que la película descubre a la novela en ese hiato donde ambas no se pueden pensar sino en su diferencia o: 
en fin, supone una historia hecha de muchos tiempos y ritmos, algo así como una multihistoria que tanto adelanta en el tiempo como se abisma, acumulativamente, en su solo momento. Como decía Enrique Lihn en un verso memorable, los latinoamericanos 'somos contemporáneos de historias diferentes' (Cornejo Polar 12).

Si la literatura, al decir de Julio Ramos, prolifera en el anuncio de su muerte y la crisis del presente, entonces, el cine le ofrece la oportunidad de observar ese clímax y realizarse en él gracias a una organización diferente de la escritura que cruza al discurso con la visualidad en la movilidad excéntrica y la sintaxis no lineal ${ }^{3}$. La tendencia a leer el cine como un contenido o ilustración de novelas y cuentos ha perdido de vista el tráfico que se produce entre imagen y palabra cuando chocan, sobornan y mezclan dos institucionalidades de la representación.

\section{ZAVALITA Y CANUDOS}

¿Qué realismo habita la obra de Mario Vargas Llosa? ¿Es un estilo transformado en utopía conservadora? La relación entre literatura y poder atraviesa su trabajo y puede leerse como el conflicto entre autonomía y modernización. Un modo de expresar este litigio sería: la letra busca purificar el territorio y controlar -artísticamente- la heterogeneidad, mientras la técnica aspira a masificar el tiempo y someter la subjetividad a una diversión melodramática. Ninguna logra vencer y ambas se dedican a vigilar sus contornos, a construir teorías y normas de protección, pero siempre hay roce, raya, sobra que encuentra espacio. De acuerdo a lo anterior, sugerimos que Mario Vargas Llosa, a pesar de su estilo purista, desobedece la regla del discurso autorreferencial y agrega a éste inflexiones nuevas: los pobres, los dictadores, los mesías, las prostitutas, los guerrilleros, los homosexuales ${ }^{4}$ traen otra visualidad a narrar, descalza y sin letra que tiene sus modelos en el cine e incorporarlos significa modificar la tradición literaria. Así, podríamos advertir que Conversación

${ }^{3}$ Características del cine moderno que ha reflexionado las estructuras narrativas y los modelos de composición.

${ }^{4}$ Significativa es la relación entre revolución y homosexualidad en La Historia de Mayta (1984); ¿Quién mató a Palomino Molero? (1986) y La Fiesta del Chivo (2000) revisan la tragedia de la polis, es decir, la incomunicabilidad entre lenguaje y política. 
en la Catedral (1969) y La Guerra del fin del mundo (1981) establecen una conexión no deseada con temas y personajes de John Huston y Orson Wells ${ }^{5}$. Las novelas guardan una comunión subyacente con aquellos filmes norteamericanos que tienen en común la adversidad, el paisaje, la muerte y la trascendencia. Dos personajes que fracasan ante una historia excedida, dos visiones destruidas por la cobardía y el mesianismo unen a un periodista decadente y un santo reaccionario. El primero descubre que la palabra escrita inmoviliza su deseo de historia, y el otro libera a los oprimidos con la oralidad celestial de la epifanía.

El periodista Santiago Zavala, testigo de una conspiración contra el gobierno, solo tiene a Ambrosio Prado para decir la palabra que no pudo usar el día que se jodió el Perú. Antonio Vicente Mendes Maciel, el Consejero, descubre que la agreste tierra del nordeste puede germinar con la voz santa de un pueblo monárquico y antiliberal. Pero contar la multiplicidad, el engranaje, la sobreimpresión que los hechos históricos demandan a estos personajes pone en evidencia que el lenguaje no basta para comprender su drama existencial y la estructura de planos-secuencias y montaje paralelo se incorpora como cita y estrategia escritural en ambos relatos. Así, cine y literatura dislocan sus campos de referencia, agregan un porvenir y reponen un deseo de orden. Un aspecto político - no menor- es la reiteración de las ideas de soberanía y comunidad, que Mario Vargas Llosa defiende y convierte en artefactos literarios y en visiones ideológicas. La ciudad, el lenguaje, el poder y la imagen necesitan una enunciación extrema que solo se puede lograr con el control de la escritura. En el interior de ese mundo se afianzan y reúnen las distancias del escritor y el político, el esteta y el liberal. La diferencia entre arte y gubernamentalidad se resuelve en el doble movimiento de imponer la letra y crear un horizonte para ella.

En suma, las imágenes viven en el texto legitimando una alegoría de la comunidad cuando el discurso no es suficiente y la escritura invade el cine cuando la soberanía parece vaciarse de destino. Por ello, el militar diligente, el revolucionario homosexual, la tía seductora, el profeta famélico, el dictador incompleto, el escritor culposo no habitan solo la memoria literaria, también

${ }^{5}$ Ambos directores producen una narrativa coral llena de personajes y acciones simultáneas que no convergen hacia un solo final. Lo mismo ocurre con las novelas del escritor peruano, siempre cargadas de conflictos, sujetos y niveles narrativos diversos. 
participan de una iconografía que Mario Vargas Llosa elabora -meticulosamentecomo sociedad latinoamericana.

\section{BIBLIOGRAFÍA}

Cornejo Polar, Antonio. "Para una teoría literaria hispanoamericana: a veinte años de su debate decisivo". Revista de Crítica Literaria Latinoamericana XXV (1999): 9-12.

Expósito, Roberto. Los Confines de lo Político. Madrid: Editorial Trotta, 1996.

Gutiérrez Alea, Tomás. La Dialéctica del espectador. México: Editorial Arte y Sociedad, 1983.

Liandrat-Guigues, Suzanne y Jean-Louis Leutrat. Cómo pensar el cine. Madrid: Cátedra, 2003.

Ramos, Julio. Los desencuentros de la modernidad en América Latina. Literatura y poder en el siglo XIX. Santiago: Editorial Cuarto Propio, 2003.

FILMS

Film Luis Pardo: http://www.youtube.com/watch?v=VRz8Tnb9A0o.

Film Los Cachorros: http://www.youtube.com/watch?v=enbo2_avhMk. 